\title{
Reuse Phosphate Gypsum Waste from Dinh Vu DAP Company to Manufacture Cement
}

\author{
Kieu Van Mat, Vu Van Chien, Nguyen Quang Bac, Doan Trung Dung, Pham Ngoc Chuc, Nguyen \\ Thi Ha Chi, Duong Thi Lim, Nguyen Thi Huong Thuy, Nguyen Nam Phuong, Dao Ngoc Nhiem
}

\begin{abstract}
Phosphogypsum disposal from Dinh Vu DAP company was used to separate phosphate and make gypsum by (NH $\neg$ 4)2SO4. The reaction time was $120 \mathrm{~min}$. The percentage of P2O5 after removal was $0.72 \%$ and met the Vietnam Standard 11833:2017 issued by Institute of Building Materials. The components in phosphogypsum could be applied to manufacture cement. The final product was mixed by PG120 : clinker : fly ash with ratio $5: 80: 15 \%(w / w)$, respectively to manufacture cement. The cement was tested compressive strength. The strength was $55 \mathrm{~N} / \mathrm{mm} 2$ after 28 days.
\end{abstract}

Index Terms - Phosphate gypsum (PG), CaHPO4.2H2O, CaSO4.2H2O, P2O5, cement, diammonium phosphate (DAP).

\section{INTRODUCTION}

In the DAP company, to manufacture a ton of acid phosphoric was discharged 4 - 6 tons of dry phosphogypsum (PG) $[1,2,3]$. PG is by product of fertilizer manufacturing process from phosphate ore used by wet method $[4,5]$. The capacity of Dinh Vu DAP company is 161700 tons per year. Therefore, the waste amount discharged to environment are very big comprised dry components and wet components. Presently, PG source discharged by Dinh Vu DAP company is about 1 million tons per year. This waste has been dumped.

H. Zhang et. al. was applied gypsum in cement with $4-5 \%$ (w/w) to reduce time of setting vicat test of cement, anti-corrugation, sulphate erosion and increase high compressive strength [6]. O. Fumie et. al. researched the effect of $\mathrm{P}_{2} \mathrm{O}_{5}$ to clinker and realized that $\mathrm{P}_{2} \mathrm{O}_{5}$ declined

Kieu Van Mat, Song Da Cao Cuong JSC, Km 28+100m, Highway No.18, Pha Lai quarter, Chí Linh city, Hai Duong province.

Vu Van Chien, Song Da Cao Cuong JSC, Km 28+100m, Highway No.18, Pha Lai quarter, Chí Linh city, Hai Duong province.

Nguyen Quang Bac, Institute of Material Sciences, Vietnam Academy of Science and Technology, No. 18, Hoang Quoc Viet street, Cau Giay district, Hanoi

Doan Trung Dung, Institute of Material Sciences, Vietnam Academy of Science and Technology, No. 18, Hoang Quoc Viet street, Cau Giay district, Hanoi

Pham Ngoc Chuc, Institute of Material Sciences, Vietnam Academy of Science and Technology, No. 18, Hoang Quoc Viet street, Cau Giay district, Hanoi

Nguyen Thi Ha Chi, Institute of Material Sciences, Vietnam Academy of Science and Technology, No. 18, Hoang Quoc Viet street, Cau Giay district, Hanoi

Duong Thi Lim, Institute of Geology, Vietnam Academy of Science and Technology, No. 18, Hoang Quoc Viet street, Cau Giay district, Hanoi.

Nguyen Thi Huong Thuy, Institute of Geology, Vietnam Academy of Science and Technology, No. 18, Hoang Quoc Viet street, Cau Giay district, Hanoi.

Nguyen Nam Phuong, Hanoi - Amsterdam high school, Hoang Minh Giam road, Trung Hoa street, Cau Giay district, Hanoi.

Dao Ngoc Nhiem, Institute of Material Sciences, Vietnam Academy of Science and Technology, No. 18, Hoang Quoc Viet street, Cau Giay district, Hanoi. compressive strength and hydrolysis energy to 28 days [7]. Presently, PG was applied to improve ground [8]. Phosphate was removed by heating sand and $P G$ in sulphuric acid environment at $250^{\circ} \mathrm{C}$ [9]. Quang N. V. et. al. was reduced gypsum in PG waste from Dinh Vu DAP company by carbon reduction method combined silicic oxide at high temperature to strengthen mechanical strength for cement [10]. In this research, PG waste treatment was applied in manufacturing cement complied Vietnam Standard TCVN 11833:2017 for PG application in cement manufacturing [11].

\section{EXPERIMENT}

PG waste: PG waste was collected from Dinh Vu DAP company in Hai Phong province. Some properties of PG waste were shown in table 1.

Table 1. Some physical properties of $P G$ waste

\begin{tabular}{|c|c|c|c|}
\hline Component & Signal & Unit & Result \\
\hline Specific density & $\mathrm{P}$ & $\mathrm{g} / \mathrm{cm}^{3}$ & 2.42 \\
\hline Natural humidity & $\mathrm{W}_{\mathrm{o}}$ & $\%$ & 1.89 \\
\hline Melted limitation & $\mathrm{W}_{\mathrm{L}}$ & $\%$ & 46.69 \\
\hline Flexible limitation & $\mathrm{W}_{\mathrm{P}}$ & $\%$ & 40.95 \\
\hline Flexible index & $\mathrm{Ip}$ & $\%$ & 5.74 \\
\hline Maximum void coefficient & $\mathrm{e}_{\max }$ & & 1.593 \\
\hline Minimum void coefficient & $\mathrm{e}_{\min }$ & & 0.666 \\
\hline Dry angular $\alpha_{\mathrm{k}}$ & $\alpha_{\mathrm{dry}}$ & angle & $39^{\circ} 39^{\prime}$ \\
\hline Wet angular $\alpha \mathrm{w}$ & $\alpha_{\mathrm{wet}}$ & angle & $31^{\circ} 29^{\prime}$ \\
\hline Maximum density of volume & $\gamma_{\mathrm{cmax}}^{\prime}$ & $\mathrm{g} / \mathrm{cm}^{3}$ & 1.385 \\
\hline Optimum humidity & $\mathrm{W}^{\prime} \mathrm{o}$ & $\%$ & 22.88 \\
\hline Permeability coefficient & $\mathrm{K}_{\mathrm{th}}$ & $10^{-6} \mathrm{~cm} / \mathrm{s}$ & 76.61 \\
\hline
\end{tabular}

Clinker was bought from Ninh Binh Vissai company. Fly ask was collected by coal furnace of Dinh Vu DAP company and pure analysis chemicals such as standard $\mathrm{NaOH} 1 \mathrm{~N}$, standard $\mathrm{H}_{2} \mathrm{SO}_{4} \quad 10 \mathrm{~N}$, concentrated $\mathrm{HCl}$, ammonium molybdate, ascobic acid, $\mathrm{NaF}$.

The chemical to remove phosphate from PG waste was used $\left(\mathrm{NH}_{4}\right)_{2} \mathrm{SO}_{4}$ followed equation:

$\left(\mathrm{NH}_{4}\right)_{2} \mathrm{SO}_{4}+\mathrm{CaHPO}_{4} \cdot 2 \mathrm{H}_{2} \mathrm{O} \rightarrow \mathrm{CaSO}_{4} \cdot 2 \mathrm{H}_{2} \mathrm{O}+\left(\mathrm{NH}_{4}\right)_{2} \mathrm{HPO}_{4}$ (1)

The experiment to remove phosphate from PG waste by $\left(\mathrm{NH}_{4}\right)_{2} \mathrm{SO}_{4}$ was carried out follows: 5 samples of solutions of $80 \mathrm{mg}\left(\mathrm{NH}_{4}\right)_{2} \mathrm{SO}_{4}$ dissolved in $200 \mathrm{ml}$ distilled water were mixed $10 \mathrm{~g}$ of PG waste by magnetic stirrer during $60,90,120$, 150 and 180 minutes.

Analysis equipments: The formation and phase modification of sample were researched by X-Ray Diffaction (XRD) in D8 Advance of Bruker (Germany) with $\lambda=1,5406$ $\mathrm{A}^{\mathrm{o}}$ of copper. Sample surface morphology was analyzed by scanning electron microscope (SEM) of Hitachi S-4800 
(Japan). TGA-DTA diagram was measured by Labsys Evo (France). Chemical components were analyzed by S2 Puma of Bruker (Germany), spectrophotometer by Carry 60-Agilent, cement sample mold, cement sample stirrer, humidity cabinet of Daihan Labtech, compressive strength equipment was standard calibration.

\section{RESULT}

\subsection{Some specific properties of $P G$ waste at Dinh $V u$ DAP company.}

PG waste was analyzed some structures, characteristics, chemical components by modern chemical physical methods such as: structure analysis, phase components by D8 Advance (Fig. 1), micro morphology by scanning electron microscope SEM-Hitachi S-4800 (Fig. 2), thermal analysis by Labsys Evo (Fig. 3), chemical component by XRF S2 Puma (Table 2). Analysis results and calculation were shown by Fig. 1, Fig.2, Fig. 3 and table 2.

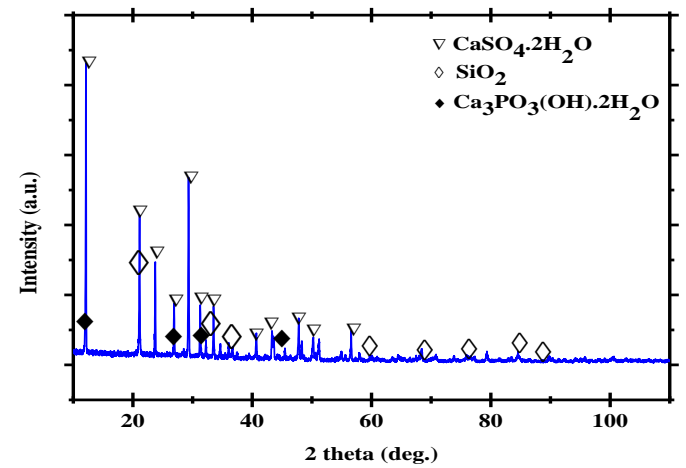

Figure 1. XRD diagram of $P G$ waste

Based on XRD diagram, phases and structures of $\mathrm{PG}$ waste were $\mathrm{CaSO}_{4} .2 \mathrm{H}_{2} \mathrm{O} ; \mathrm{Ca}_{3} \mathrm{PO}_{3}(\mathrm{OH}) .2 \mathrm{H}_{2} \mathrm{O}$; quartz and hydrated iron oxide $\mathrm{FeO}_{2}(\mathrm{OH})$.

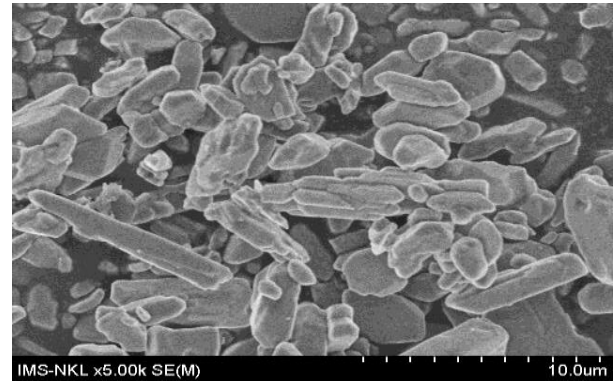

Figure 2. SEM of PG waste

Fig. 2 was shown that surface morphology of PG waste was small plate. Therefore, they were dispersed easily and blended to make additives for construction field such as bricks, gypsum mortar, panel, baffle plate, cement

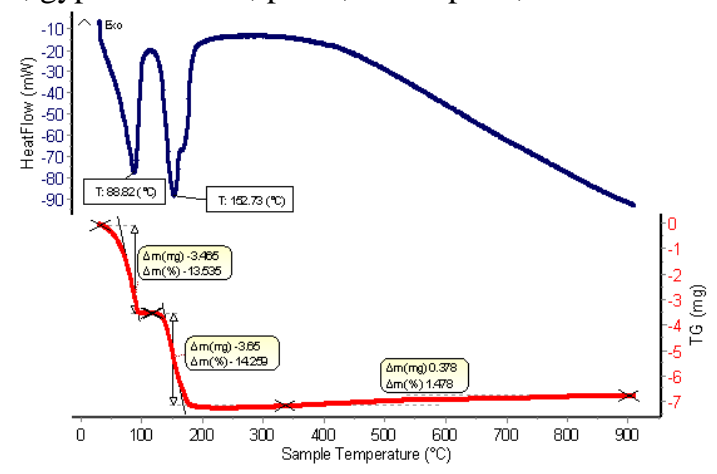

Figure 3. DTA - TGA of PG waste
Fig. 3 was shown that the weight was lost $13.54 \%$ from 114.28 to $125^{\circ} \mathrm{C}$ corresponded endothermic peak on DTA at $88.82^{\circ} \mathrm{C}$. This reduction weight was caused by losing hydration water of $\mathrm{CaSO}_{4} \cdot 2 \mathrm{H}_{2} \mathrm{O}$ and $\mathrm{Ca}_{3} \mathrm{PO}_{3}(\mathrm{OH}) \cdot 2 \mathrm{H}_{2} \mathrm{O}$ crystals.

From $125^{\circ} \mathrm{C}$ to $400^{\circ} \mathrm{C}$, the weight was lost $15.75 \%$ corresponded endothermic peak at $152^{\circ} \mathrm{C}$ on DTA. The reduction weight was equal water crystal in $\mathrm{CaSO}_{4} \cdot 2 \mathrm{H}_{2} \mathrm{O}$ and hydrated iron oxide. When temperature was higher than $400^{\circ} \mathrm{C}$, the weight was not changed. Therefore, $\mathrm{PG}$ waste was stable at temperature higher than $400^{\circ} \mathrm{C}$ and suitable to manufacture cement.

\begin{tabular}{|c|c|}
\hline Component & $\%$ weight \\
\hline $\mathrm{Na}_{2} \mathrm{O}$ & 0.06 \\
\hline $\mathrm{K}_{2} \mathrm{O}$ & 0.043 \\
\hline $\mathrm{MgO}$ & 0.022 \\
\hline $\mathrm{F}$ & 0.16 \\
\hline $\mathrm{Cl}$ & 0.004 \\
\hline $\mathrm{pH}$ & 2.8 \\
\hline $\mathrm{CaO}$ & 25.51 \\
\hline $\mathrm{SO}_{3}$ & 38.37 \\
\hline $\mathrm{SiO}_{2}$ & 8.47 \\
\hline $\mathrm{P}_{2} \mathrm{O}_{5}$ & 1.02 \\
\hline $\mathrm{Al}_{2} \mathrm{O}_{3}$ & 0.58 \\
\hline $\mathrm{TiO}_{2}$ & 0.19 \\
\hline $\mathrm{MnO}$ & 0.23 \\
\hline $\mathrm{Fe}_{2} \mathrm{O}_{3}$ & 0.21 \\
\hline $\mathrm{SrO}$ & 0.09 \\
\hline $\mathrm{MgO}$ & 0.07 \\
\hline
\end{tabular}

Table 2. Chemical components of PG waste

Analysis results of PG waste were shown that percentage of water was $27.7 \%$ and that of phosphate by $\mathrm{P}_{2} \mathrm{O}_{5}$ was $1.02 \%$. This percentage of $\mathrm{P}_{2} \mathrm{O}_{5}$ was higher than limited standard $0.8 \%$ comprised by dissolved and undissolved form [11].

Otherwise, $\mathrm{pH}$ of PG waste was 2.8. When mixed with clinker, it was caused by thermogenic with lime.

\subsection{Some characteristics of $P G$ waste after phosphate removal by $\left(\mathrm{NH}_{4}\right)_{2} \mathrm{SO}_{4}$ from $\mathrm{PG}$ waste}

Table 2 was shown that PG waste could not be used to manufacture cement with high compressive strength because of high percentage of $\mathrm{P}_{2} \mathrm{O}_{5} 1.02 \%$. Therefore, phosphate was needed to remove. $\left(\mathrm{NH}_{4}\right)_{2} \mathrm{SO}_{4}$ was applied to remove phosphate and followed by equation (1). 5 samples at different reaction times such as 60, 90, 120, 150 and 180 minutes were tested. After reaction times, samples were filtered and washed by distilled water to $\mathrm{pH}=7$. Samples were dried during 8 hours at $120^{\circ} \mathrm{C}$ to constant weight. Total percentages of $\mathrm{P}_{2} \mathrm{O}_{5}$ of samples were measured by following Vietnam Standard 11833:2017. Table 3 was shown the percentages of $\mathrm{P}_{2} \mathrm{O}_{5}$ at different reaction times.

Table 3. Percentages of $\mathrm{P}_{2} \mathrm{O}_{5}$ of $\mathrm{PG}$ after treated by using $\left(\mathrm{NH}_{4}\right)_{2} \mathrm{SO}_{4}$ at different reaction times.

\begin{tabular}{|c|c|c|}
\hline Sample & Time $(\mathrm{min})$ & $\% \mathrm{P}_{2} \mathrm{O}_{5}(\mathrm{w} / \mathrm{w})$ \\
\hline $\mathrm{PG}$ & 0 & 1.02 \\
\hline $\mathrm{PG}_{60}$ & 60 & 0.83 \\
\hline $\mathrm{PG}_{90}$ & 90 & 0.78 \\
\hline $\mathrm{PG}_{120}$ & 120 & 0.72 \\
\hline $\mathrm{PG}_{150}$ & 150 & 0.69 \\
\hline $\mathrm{PG}_{180}$ & 180 & 0.66 \\
\hline
\end{tabular}


Table 3 was shown that samples from 90 to 180 minutes had percentage of $\mathrm{P}_{2} \mathrm{O}_{5}$ lower than $0.8 \%$ [11]. Therefore, reaction time selected to remove phosphate was 120 minutes.

PG sample after phosphate treatment at 120 minutes was analyzed structures, properties, chemical components similar PG waste above. The analysis result and calculation were shown by table 4 and from Fig. 4 to Fig. 6 .

Table 4. Chemical components of $P_{120}$ after treated by

\begin{tabular}{|c|c|}
\hline \multicolumn{2}{|c|}{$\left(\mathrm{NH}_{4}\right)_{2} \mathrm{SO}_{4}$} \\
\hline Component & \% weight \\
\hline $\mathrm{CaO}$ & 25.9 \\
\hline $\mathrm{SO}_{3}$ & 38.51 \\
\hline $\mathrm{F}$ & 0.028 \\
\hline $\mathrm{P}_{2} \mathrm{O}_{5}$ & 0.72 \\
\hline $\mathrm{MgO}_{2}$ & 0.17 \\
\hline $\mathrm{Al}_{2}$ & 0.82 \\
\hline $\mathrm{SiO}_{2}$ & 11.83 \\
\hline $\mathrm{TiO}_{2}$ & 0.29 \\
\hline $\mathrm{MnO}$ & 0.02 \\
\hline $\mathrm{FeO}$ & 0.3 \\
\hline $\mathrm{Cl}$ & 0.007 \\
\hline
\end{tabular}

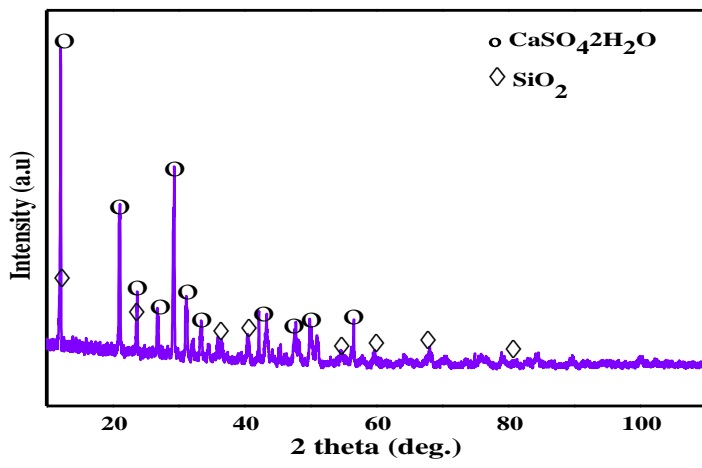

Figure 4. XRD of $P G_{120}$

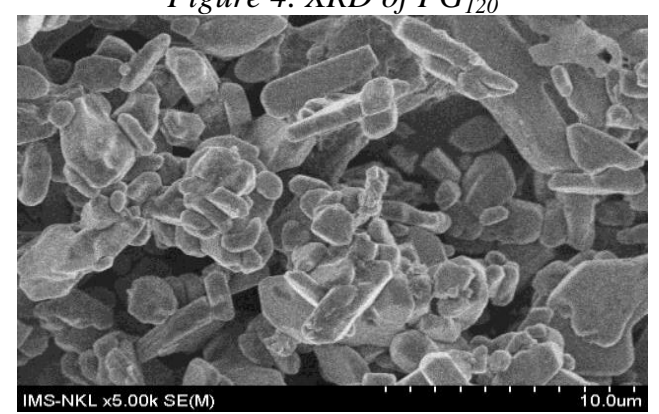

Figure 5. SEM of $P G_{120}$

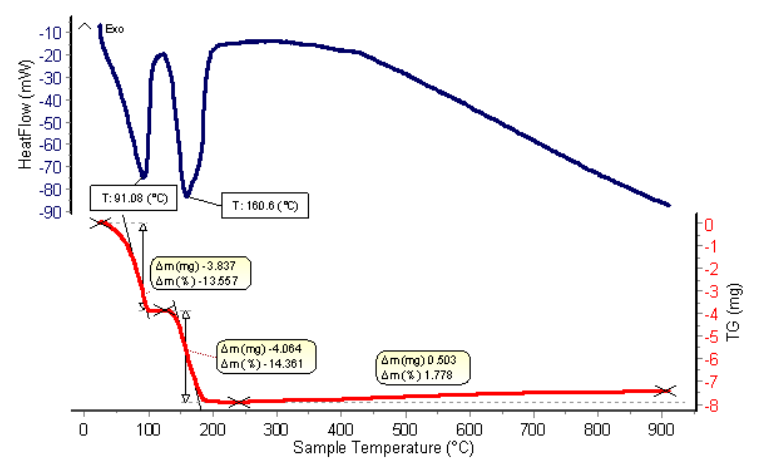

Figure 6. DTA - TGA of $P G_{120}$

Chemical components of $\mathrm{PG}_{120}$ after phosphate treatment were comprised gypsum $\mathrm{CaSO}_{4}, 2 \mathrm{H}_{2} \mathrm{O}$ and quartz (Fig. 4).
Fig. 5 was shown that morphology of $\mathrm{PG}_{120}$ was small uniform plate compared with $\mathrm{PG}$ waste. Fig. 6 was shown that the reduction weight was $14 \%$ on TGA from $125^{\circ} \mathrm{C}$ to $200^{\circ} \mathrm{C}$ corresponded by endothermic peak on DTA at $160^{\circ} \mathrm{C}$. This was lost crystallization water from $\mathrm{CaSO}_{4} \cdot 2 \mathrm{H}_{2} \mathrm{O}$ to $\mathrm{CaSO}_{4}$.

From above results, $\mathrm{PG}_{120}$ was suitable for manufacturing cement by complying Vietnam Standard 11833:2017 [11].

\subsection{Manufacturing cement by using $P G_{120}$}

Phase components of fly ash at coal workshop of Dinh $\mathrm{Vu}$ DAP company and clinker at Ninh Binh Vissai company was analyzed by D2 Phaser with Topass BBQ software. Fly ash was comprised gypsum $2 \%$, muscovite/illite $8 \%$, microcline $2 \%$, mullite $2 \%$, quartz $18 \%$ and amorphous phase $68 \%$ $(w / w)$. Higher percentage of amorphous phase, higher strength of cement was. Clinker was comprised $\mathrm{C}_{3} \mathrm{~S} 67.29 \%$, $\mathrm{C}_{2} \mathrm{~S} 11.37 \%$, Total aluminum $4.88 \%$, Ferit $14.68 \%, \mathrm{CaO}$ $0.13 \%, \mathrm{Ca}(\mathrm{OH})_{2} 0.23 \%$, periclase $0.31 \%$, quart $0.03 \%$, Arcanite $1.05 \%$, langbeinite $0.02 \%$, aphthitalite $0 \%$.

Cement was made by grinding mixture of clinker: $\mathrm{PG}_{120}$ : fly ash with ratio $80: 5: 15 \%(w / w)$, respectively. Compressive strength was measured by Vietnam Standard TCVN 6016:2011 [12] estimated by 3, 7, 28 days. The results and calculation were shown by figure 7 .

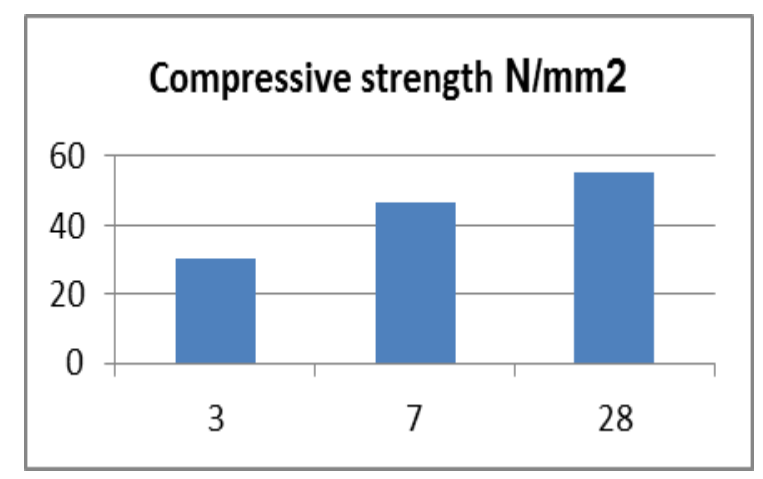

Figure 7. Compressive strength of cement used $5 \%$ of $P G_{120}$ at 3,7 and 28 days

Compressive strength of cement sample of $5 \% \mathrm{PG}_{120}$ after 3 , 7, 28 days were 30,44 and $55 \mathrm{~N} / \mathrm{mm}^{2}$, respectively. Compressive strength at 28 days was $55 \mathrm{~N} / \mathrm{mm}^{2}$ was equal PC 50 grade.

\section{CONCLUSION}

Researching specific properties of PG waste by modern chemical physical analysis methods and realizing that PG waste had small plate; phase components was $\mathrm{CaSO}_{4} \cdot 2 \mathrm{H}_{2} \mathrm{O}$, $\mathrm{Ca}_{3} \mathrm{PO}_{3}(\mathrm{OH}) \cdot 2 \mathrm{H}_{2} \mathrm{O}$, quartz and hydrated iron oxide; phosphate calculated by $\mathrm{P}_{2} \mathrm{O}_{5}$ was $1.02 \%(\mathrm{w} / \mathrm{w})$ and $\mathrm{pH}$ was 2.8 .

Researching to remove phosphate to $\mathrm{PG}$ waste by using $\left(\mathrm{NH}_{4}\right)_{2} \mathrm{SO}_{4}$ during 120 minutes and analyzing $\mathrm{PG}_{120}$ structures, phase components, morphology. $\mathrm{PG}_{120}$ had small uniform plate. Phase components were main $\mathrm{CaSO}_{4} \cdot 2 \mathrm{H}_{2} \mathrm{O}$; quartz. Percentage of $\mathrm{P}_{2} \mathrm{O}_{5} \quad 0.72 \%$ was suitable for manufacturing cement followed Vietnam Standard TCVN 11833:2017.

$\mathrm{PG}_{120}$ was tested to manufacture cement. The compressive strength of cement after mixed clinker: $\mathrm{PG}_{120}$ : fly ash with ratio 80: 5: $15 \%(\mathrm{w} / \mathrm{w})$, respectively was $55 \mathrm{~N} / \mathrm{mm}^{2}$ after 28 days corresponded PC50 grade. 


\section{ACKNOWLEDGEMENT:}

This project is supported by science and technology project belonged to KH\&CN program according to Contract No. 67/15-ĐTĐL.CN-CNN.

\section{REFERENCES}

[1] J.H. Potgieter, S.S. Poguieter, R.I. McCrindle, C.A. Strydom, "An investigation into the effect of various chemical and physical treatments of a South African PG to render a suitable as a set retarder for cement", Cement and Concrete Research, Vol. 33 (2003), pp. 1223-1227.

[2] M. Singh, M. Garg, C.L. Verma, S.K. Handa, R. Kumar, "An improved process for the purification of PG”, Constr. Build. Mater., Vol. 10 (8), 1996, pp. 597-600.

[3] E.M. Van der Merwe, C.A. Strydom, "Purification of South African PG for use as Portland cement retarder by a combined thermal and sulphuric acid treatment method", South African J. Sci., Vol. 100, 2004, pp. 411-414.

[4] H. Tayibi, M.Choura, F. A. López, F. J. Alguacil, A. López-Delgado, "Environmental impact and management of phosphogypsum". $J$. Environ. Manage., Vol. 90, 2009, pp. 2377-2386.

[5] C. Conklin, "Potential ues phosphogypsum and associated risks", US Environmental Protection Agency, 1992.

[6] H. Zhang', Z. Lin* and D. Tong. "Influence of the type of calcium sulfate on the strength and hydration of portland cement under an initial steam-curing condition" Cement and Concrete Research, Vol. 26, No. 10, 1996, pp. 1505-15.

[7] F. Osawa, N. Shirahama, M. Yamashita and H. Tanaka. "Effects of phosphorus oxide in clinker and cement on the properties of high content belite cement" Cement Science and Concrete Technology, Vol.69, 2015, pp. 23-28.

[8] N. Degirmenci, A. Okucu, A. Turabi, "Application of phosphogypsum in soil stabilization" Building and Environment, Vol.42, 2007, pp 3393-3398, 2007.

[9] W. Gauster, L. Danube, W. Miller, F. Weinrotter. "Process for removing fluorine and phosphate from gypsum produced in the manufacture of phosphoric acid", U.S. Patent, 3,547,581,1970

[10] N. V. Quang, L. V. Bình, L. T. Vinh, "Quá trình khử gypsum bằng cacbon hoạt tính kết hợp với silic dioxit ở nhiệt độ cao", Vietnam J. Chem., 2015, pp. 75-78.

[11] TCVN 11833:2017, Thạch cao phospho dùng để sản xuất xi măng.

[12] TCVN 6016:2011, Xi măng- phuong pháp thủ-xác định cuờng độ.

Dao Ngoc Nhiem Bachelor' degree at VNU Hanoi University of Science $\mathrm{Ph}$. D' degree Vietnam Academy of Science and Technology and finished his internship at KIMS, Korea about nanopowders technology.

Most recent research:

1. Quang Bac Nguyen, Dinh Phuong Vu, Thi Ha Chi Nguyen, Trung Dung Doan, Ngoc Chuc Pham, Thi Lim Duong, Tran Dai Lam, Long Giang Bach, Hong Con Tran and Ngoc Nhiem Dao. Photocatalytic activity of $\mathrm{BiTaO}_{4}$ nanoparticles for the degradation of methyl orange under visible light, Journal of Electronic Materials, 48(5), 3131-31366 (2019).

2.Dao Ngoc Nhiem, Nguyen Quang Bac, Doan Trung Dung, Pham Ngoc Chuc, Nguyen Thi Ha Chi and Duong Thi Lim. Novel anti-ultraviolet performances of thin films polyurethane containing nano-mixed oxides $\mathrm{CeO}_{2}-\mathrm{TiO}_{2}$, Advances in Mechanical Engineering, 2018, Vol. 10(11) 1-5

3. L. M. Dai, D. N. Nhiem, D. T. Lim, and N. D. Van. "Nanostructured $\mathrm{CeO}_{2}-\mathrm{Al}_{2} \mathrm{O}_{3}$ Catalytic Powders for m-Xylene and Toluene Combustion", Materials Transactions, vol. 54, 2013, pp. 1060-1062.

4. DN Nhiem, LM Dai, ND Van, and DT Lim. "Catalytic oxidation of carbon monoxide over nanostructured $\mathrm{CeO}_{2}-\mathrm{Al}_{2} \mathrm{O}_{3}$ prepared by combustion method using polyvinyl alcohol", Ceramics International, vol. 39, Apr. 2013, pp. 3381-3385.

5. NN Dao, M. Dai Luu, QK Nguyen, BS Kim. "UV absorption by cerium oxide nanoparticles/epoxy composite thin films", Advances in Natural Sciences: Nanoscience and Nanotechnology, Dec. 2011, pp. 045013.

Nguyen Quang Bac Bachelor's degree majoring in chemistry at VNU Hanoi University of Science.

Doan Trung Dung Bachelor's degree majoring in chemistry at VNU Hanoi University of Science. Recent research: Minh Dai Luu, Ngoc Nhiem Dao, Duc Van Nguyen, Ngoc Chuc Pham, The Ninh Vu, and Trung Dung
Doan, “ A new perovsite-type $\mathrm{NdFeO}_{3}$ adsorbent: Synthesis, characterization, and As(V) adsorption", Vol. 7, 2016, to be published.

Pham Ngoc Chuc Bachelor's and Master's degree at VNU Hanoi University of Science. Recent research: Minh Dai Luu, Ngoc Nhiem Dao, Duc Van Nguyen, Ngoc Chuc Pham, The Ninh Vu, and Trung Dung Doan, “ A new perovsite-type $\mathrm{NdFeO}_{3}$ adsorbent: Synthesis, characterization, and As(V) adsorption", Vol. 7, 2016, to be published.

Nguyen Thi Ha Chi Bachelor's and Master's degree at VNU Hanoi University of Science.

Duong Thi Lim Bachelor' degree at VNU Hanoi University of Science $\mathrm{Ph}$. D' degree Vietnam Academy of Science and Technology.

Recent research:

1. Van Nguyen Duc and Dao Ngoc Nhiem, "Low-temperature Synthesis of $\left(\mathrm{K}_{0.5} \mathrm{Na}_{0.5}\right) \mathrm{NbO}_{3}$ Nanopowders by a Urea Sol-Gel Combustion Method", Chemistry Letters, vol 43. 2014, pp. 1438-1440.

2. L. M. Dai, D. N. Nhiem, D. T. Lim, and N. D. Van. "Nanostructured $\mathrm{CeO}_{2}-\mathrm{Al}_{2} \mathrm{O}_{3}$ Catalytic Powders for m-Xylene and Toluene Combustion", Materials Transactions, vol. 54, 2013, pp. 1060-1062.

3. DN Nhiem, LM Dai, ND Van, and DT Lim. "Catalytic oxidation of carbon monoxide over nanostructured $\mathrm{CeO}_{2}-\mathrm{Al}_{2} \mathrm{O}_{3}$ prepared by combustion method using polyvinyl alcohol", Ceramics International, vol. 39, Apr 2013, pp. 3381-3385.

Corresponding author: Nguyen Quang Bac and Dao Ngoc Nhiem Institude of Materials Science, Vietnam Academy Science and Technology 18 Hoang Quoc Viet, Cau Giay, Hanoi, Vietnam 